\title{
The Effect of Project Based Learning on Writing Business Letters
}

\author{
Yulia Rizki Ramadhani ${ }^{1}$, Abdul Rahman Suleman Siregar ${ }^{2}$, Abdurrozzaq Hasibuan $^{3}$ \\ \{yuliadamanik@dosen.ugn.ac.id ${ }^{1}$, ragilzhillan@gmail.com ${ }^{2}$, rozzaq@uisu.ac.id ${ }^{3}$ \} \\ ${ }^{1}$ English Department, Universitas Graha Nusantara, Padangsidimpuan, Indonesia \\ ${ }^{2}$ Department of Development Economics, Universitas Graha Nusantara, Padangsidimpuan, Indonesia \\ ${ }^{3}$ Industrial Engineering, Faculty of Engineering, Universitas Islam Sumatera Utara, Medan, Indonesia
}

\begin{abstract}
This research investigated the implementation of the use of PBL in improving the students' writing ability. The objectives of this research was to find out whether there is a significant effect of using PBL toward writing ability or not. This research is colaborating between english lecturer and development economic lecture where the output of this research is a module (a material collection of writing business letters technique including the sample). This research was carried out on the third semester students of Development Economics Department. The writer employed a quasiexperimental design. This research assigned one groups consists of 20 students. Based on the result of research the mean score of post test (79.80) was higher than the pre test (69.50). The paired t-test calculation shows the result of paired sample test $(0.00<0.05)$ in which there is a significant difference between pre-test and post-test scores after having treatments. In addition, the results suggest that teaching through PBL gives positive effects on students' ability in writing business letters.
\end{abstract}

Keywords: project-based learning, business letter, writing skill

\section{Introduction}

English as an international language places the first position in the world. English plays important role, we study English because we need it in many aspects. English is used to express our idea, opinion and feeling to other people from other countries. English is also needed to face globalization era, where we get much information from all over the world without mastering English we will miss some important things we need. In learning English we have to know that there are four skills we must comprehend. They are listening, speaking, reading and writing. In this research researchers will discuss about students' ability in writing business letter. Writing has become problem for to the students of Development Economics Department. Some of the problems that are faced by the students are less of developing idea and vocabulary especially in business topic. So the students get difficulties to develop their ideas what they want to write and they do not know the vocabulary that refers to the topic of writing that they want to make. Because writing is complex activity, students tend to fell writing is difficult and which make them bored in writing. It becomes a challenge for the teacher on how to make the students to be competent in writing business letter. Project Based Learning is one of taditional learning method in which teachers engage students in the learning process by using the project as the core of learning. 
English for economy has a more difficult term compared to general English because associated with particular vocations. In addition, variations form of English in economics is very complex and general needs special attention because it is related to the application in the workforce. Based on the above it is necessary to labor should be the focus of the approach Specific English Purpose (ESP) where the learner and his needs became a major consideration in determining process and direction learning for the purpose teaching effectively and efficient (Hutchinson \& Waters, 1987; Robinson, 1991).

Language learning English economy should be adjusted with what the learners need at the workforce so that the students when graduated not only mastered the subject of economics but also have more ability in English and apply it in the workforce.

Based on the background of the study the problem reseachers focus on knowledge about business writing, the term or common expressions which are used writing business letter, the defenition, intention, purposes, and style of business letter.

Project Based Learning is a teaching method which is based on student centered learning. It has a mission to increase students' participation during the teaching and learning process. Project work is a part of cooperative learning (Stoller, 2002). The students have to work on their own, in a small group, or as a whole-class.

In PBL, the project is the central teaching strategy, students encounter and learn the central concepts of the discipline via the project (Thomas, 2000). By teaching using PBL, the students are given some systematic tasks related to the business letter, then in the end of the meeting the students will result on some business letters which can be used by themselves or others. Based on above, the reseachers formulate the research problem is there a significant difference between pretest and posttest means of the group?

This research is colaborated between english lecturer and development economic lecture where the output of this research is a module (a material collection of writing business letters technique including the sample). The researchers hoped by applying Project Based on Learning will attract student's interest and stimulate them to enjoy in writing business English letter.

\section{Literature Review}

Writing is one of the productive skills which involves communicating a message in the form of letters and symbols. Communicating means sending certain information to others, therefore, a message must have a purpose (Spratt, Pulverness, and Williams, 2005). Writing is a language skill to communicate indirectly. Suparmo and Yunus (2008) describes writing can be defined as an activity of delivering messages (communications) with written language as its tool. Writing is an activity and a skill for expressing ideas through written means. Therefore, it can be argued that writing is a series of processes from thinking about ideas to be delivered to reader and deciding how to express or present the idea in sentence sequence correctly (Mustofa, 2000). In principle, the main function of writing is as a tool to communicate indirectly. In business activity also very important. For example in business letter writing.

The business letter is a communication tool as well as written documentation used to communicate with internal or external companies. With the business letter was expected to convey information complete and appropriate in order to achieve the goals of the company / organization. According Sedarmayanti (2009), the letter is a written communication from one group and addressed to the other group for delivered the news. 
While Barthos (2005) argued that the letter is a written communication tool from one group and addressed to the other group to delivered the news.

From some opinions on above, it can be taken the meaning of the letter is a written statement made with aim to convey information to other groups and the written communication tool that concerns interests of duties and activities of the company. So, this letter is very important for helping facilitate the goals of the organization.

Writing the good business messages in form of letters, reports, and proposals for internal and external corporate organizations and memos is routine in the business world. Moreover, the writing of business letters that give a positive impression or a good image for the readers is something that needs to get attention for the company's organization.

Messages delivered are likely to succeed if the reader has good impression, or they can receive well-delivered messages

1. Good will about the job. How to get a suitable job applicant and choose the right people for job vacancy is an easy task. Therefore, an organisaisi that needs new employees should really make the selection and recruitment process exactly as desired.

2. Good news about the product. To safeguard their customers, the company can develop their business strategy with competitive product pricing, quality products, the selection of appropriate promotional methods, and the proper selection of distribution channels.

3. Good will messages. Good will is a positive feeling that can encourage people to maintain a business relationship. It can encourage good relationships with various parties, such as customers, suppliers or other business actors by delivering good messages that are irresistibly related to business objectives.

Learning writing is one learning that an important role. The selection of appropriate strategies and approaches in learning is something that the teacher should consider.

Project-Based Learning (PBL) is a learning model that involves students in a project based on a problem and finally the student can produce a real work. (Colley, 2008).

In addition, Fried-Booth (2002) state the definition of project-based learning as studentcentered and driven by the need to create an end-product. PBL is a means to create an endproduct in real-world environment with confidence and independence. Solomon (2003) says that project-based learning is a process of learning that students are responsible for their own education. Students work collaboratively to solve problems that are authentic, curriculumbased, and often interdisciplinary. Throughout the process, the students share their ideas, resources, and expertise. Project based learning helps students to inquire. Students drive their own learning through inquiry, as well as work collaboratively to create projects that reflect their knowledge (Bell, 2010). Moreover, project based learning fosters students to critical thinking. It causes students to get engaged in critical thinking in order to construct their own meaning by applying what they learn (Krauss and Boss, 2013).

\section{Methodology Of Research}

In this research, the writers use a quantitative research design where it's employed the Quasi Experimental Research. In this design, subjects of the study were assigned to treatment groups, namely: the Experimental group and Control group. This sample involved from the third semester of Development Economics Department at University of Graha Nusantara. There were 20 students included to be the sample. This study employed the following instruments: (a) research-made report writing pretest - posttest; and (b) lesson designs for the 
experimental group and control group. Research instruments were subjected to content validation and reliability test.

For details, the implementation of treatmet of this research as follows:

a. The researchers gived the module in the form of materials about the techniques of writing business letter in English as well as.

b. The researchers gived explanation about business letter writing, such as:

- Confirmation, to confirm arrangements made between sender and recipient

- Acknowledgement, to acknowledge receipt of a letter, order or other item

- Enquiry, to request information or prices

- Reply, to respond to an enquiry

- Complaint, to criticize poor service or goods.

- Adjustment, to respond to the complaint and hopefully make amends

- Collection letters, to obtain settlement of a debt

- Sales letter, to sell goods or services

c. The researchers gived explanation about format of business letters (opening lines: adrress of applicant, date of letter, company profile, solutation, title of letter, body of letter, closing sentences: complimentary closing, enclosure)

d. The researchers gived explanation about style of letters in use to writing business letters

e. The researchers provide examples in creating business letters.

f. And the researchers gived them a project to make reply letters in a business letter, such as groups assignment. One group completed the inquiry letters which contents to request information or prices, and the other group completed a reply letter which contents to respond to an inquiry

A test is a method of measuring a person's ability or knowledge in a given domain (Brown, 2001) . The test used writing rubric for writing tests. Those tests would result in scores that would be compared later to find the improvement of the students' writing ability. When learning teaching process happen the teacher give treatment using project based learning and to take the score the researchers given post test to the student to know the effect of using project based learning to the student's ability in writing business letter.

In Post-test the writers ask the students make the letter about an adjustment letter, which its content to respond the complaint and hopefully make amends in business activity using business terms on the student's words. The example of these business terms like : 


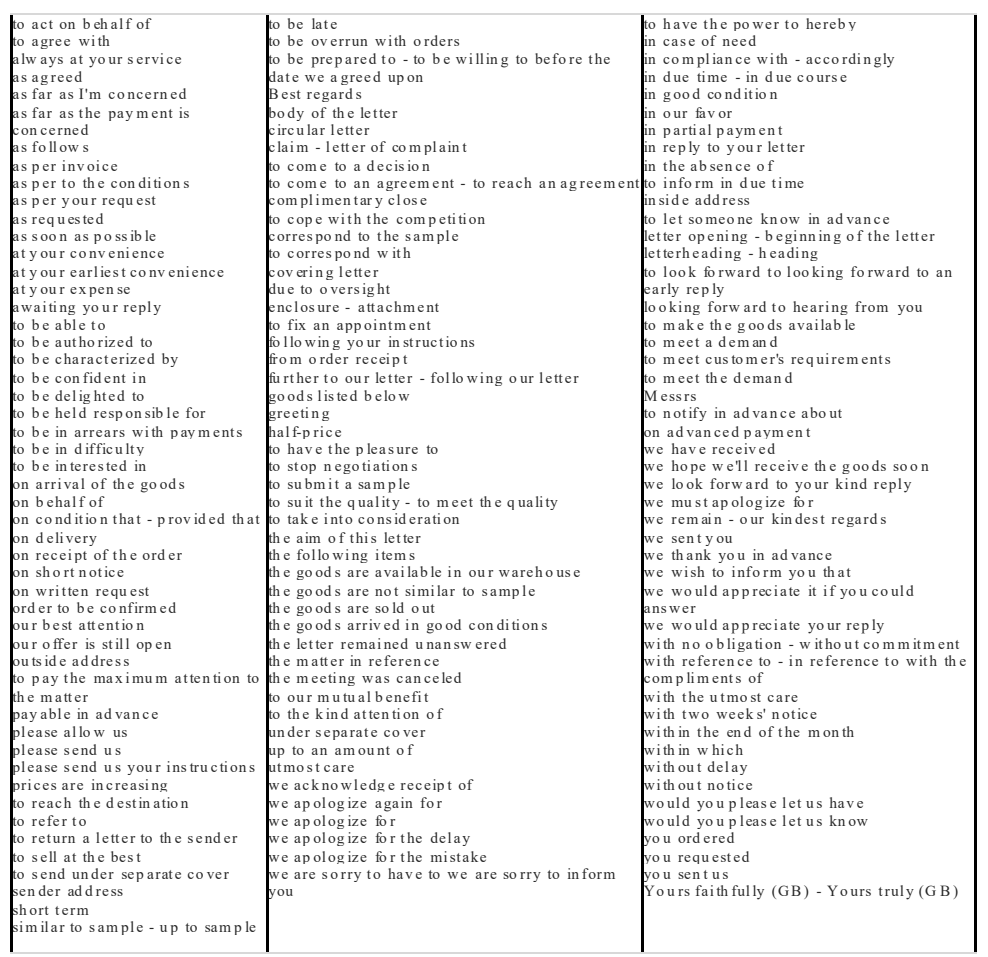

(Beare, K. 2017)

To know the students' mastery level in their writing business letter, the data analyze by using three stages based the identification of the problem in this research as follows:

Table 1: Writing Rubrics.

\begin{tabular}{|c|c|}
\hline Categories & Score \\
\hline Format the business letters & 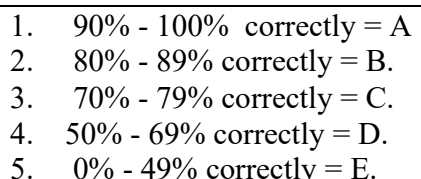 \\
\hline Letter Styles & 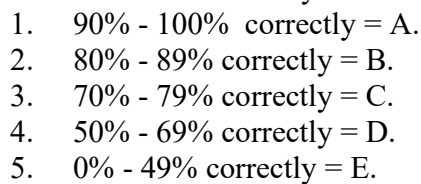 \\
\hline $\begin{array}{l}\text { The term vocabulary which are } \\
\text { used writing business letter }\end{array}$ & $\begin{array}{ll}\text { 1. } & 90 \%-100 \% \text { correctly }=\mathrm{A} . \\
\text { 2. } & 80 \%-89 \% \text { correctly }=\mathrm{B} . \\
\text { 3. } & 70 \%-79 \% \text { correctly }=\mathrm{C} . \\
\text { 4. } & 50 \%-69 \% \text { correctly }=\mathrm{D} . \\
\text { 5. } & 0 \%-49 \% \text { correctly }=\mathrm{E} .\end{array}$ \\
\hline
\end{tabular}


The technique of collecting data in this researh, could be diagrammed as shown below:

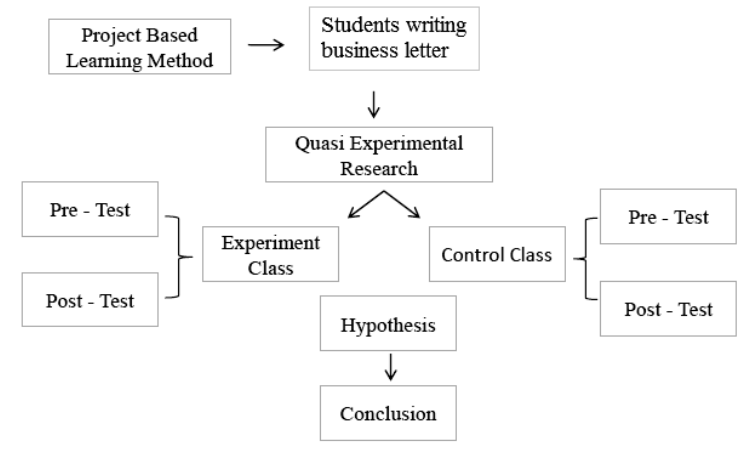

Fig.1. The technique of collecting data.

The data were analyzed using t-test computation to determine there the effect of Project Based Learning on Writing Business Letter.

\section{Finding And Discussion}

The result of this research report informs about the process of pre-test, treatment, and post-test which had been applied to the students of development economic department. the result of students learning before implementation of PBL is obtained during the pre test. Pre test was given to the students in order to measure the students'competence before they were given the treatment . According to Wiersama (1991: 106), Pretest is gives to the students before they get a treatment. Pre-test was given before the treatments. The researchers came to the class, explained the material and told them what they had to do. The pre-test was taken consist of twenty students. It consists of only one question. The writer asked the students to make a complaint letter, which its content to criticize poor service or goods in business activity. The total score which be turned out by 20 students is 1290 .

Most students indicate that the contents of business letters at the pre test are classified not having letter writing requirements. Submission in the contents of the letter still has not shown a good focus so that the purpose and objectives of writing letters is not clear. In addition, there is no style in the writing of letters and terms of format of business letters. Without a good understanding of the concept, style and format of letter writing, students very difficult to create a business letter.

The results of student writing in vocabulary mastery is still relatively limited. In addition, the vocabulary is still a lot of confusing and often occur in form errors and vocabulary selection. It is related to other students' language skills. Vocabulary is very important to make an idea and fluently in written communication. The result from their sentences are also not communicative. Based on the description, the role of teachers is needed in the classroom. The role of teachers is also required to be thorough on the project of students and not just give an assessment. Based on the theory that has been applied in the process of learning in the classroom, there are following of the implementation of project-based learning. First stage is the presentation of the problem. The second is planning. The third is to set the schedule. The 
fourth stage is to monitor the making of the project. The fifth stage is to make an assessment. While the last stage relates to evaluation.

Based on the treatment that has implemeted, the reseachers correlated the skills of students in developing the content with the first stage implemented in the sequence of implementation of project-based learning. This stage is the presentation of problems. The problem has a correlated to real faced by students in the workforce. When students was conditioned to record problems and filter out the problems, students have at least two topics or two issues that will be developed in writing a business letter. Early provision of preparing the problem is most contributed to easier the process of writing business letters for students. The problems make content developing interrelated. The developing of a good content can support the assessment of other criteria that are used as assessment.

Related to be taught material about the style and format of business letter writing in the learning process, students are considered to have recognized the business letter. With given this material students have gained knowledge of the style, format and vocabulary in business letter writing. Most students have created business letters according to the structure of the letter as theoretically taught. However, not all students succeeded in applying it. But this also means that students have been able to recognize the structure of business letters with completeness as they are comprehend. Vocabulary mastery has very important correlation in writing skills. Vocabulary is the main basic to used to deliver information and ideas. he function of vocabulary mastery is the same as both spoken and written communications. Related to that, there are some descriptions of the improvement that researchers can describe.First, the vocabulary increasing was related to the preparation of students. This stage is given information about the vocabulary was used in business letter writing, preparation of framework with by the development of good writing material. Limited vocabulary related to the ability for developing the content that is also limited. With the development the right content, the right writing letter material preparation, allowing students given the opportunity to read. This causes the mastery of vocabulary increasing. The presentation and evaluation process has been in project-based learning also required students to improve the writing results together. Students get used for editing skill and also increased their vocabulary. Although this process taked relatively long time.

During the process of implementing the Project Based Learning Model the students are divided into groups. Students begin to learning process with their group according to the learning process in the Lesson Plan. Here are some factors that caused students' score increasing in the post test. The first factor is teacher. Teachers implement learning by presenting a number of issues that are relevant to the workace that will be faced by students. In addition, teachers also guide students during given the treatment taught Project Based Learning Model. The teacher as a facilitator who guides the treatment of Project Based Learning in the classroom. During the course, students are conditioned to learn naturally as well as the usual course of learning that everyday in the classroom. The next factor is learning process. The results of the post test was known to show improvement students' score were having learned about the concept of style, the format of writing business letters. Students get more understand with given them examples of business letters. The next stage was given students opportunity to produce business letters together with their study groups. The next process is comparing business letters that students have produced with their groups with business letters from other groups. After all these processes were implemented, teachers and students reflect on the difficulties that faced of learning groups during the project based learning model. 
Learning process is supported by using of media in the classroom. To support student understanding, then when the implementation of learning used projector. The projector displays the learning points in Microsoft Power Point view. Students are also required to display their business letters that have been created using this projector. With the presentation of business letters using projectors, other students may respond advantages and disadvantages of business letters from other groups. Factor of Teacher, learning process, with the use of instructional media during the implementation of the Project Based Learning Model, make the students' writing skills of business letter have improving at the post test when compared to business letter during the pre test. Improved writing skills of business letter is experienced at aspect of the assessment. After doing the pretest and postes of students' writing skills show a positive influence. Student value data at the pre test and post test calculated using the t-test formula. The using of this formula to describe the level of significance of treatment in form of Project Based Learning Model in the class.

The post-test was taken consist of twenty students. Post teaching was about giving posttest about Adjustment letter, which its content to respond the complaint and hopefully make amends in business activity. Then given feedback and evaluation about their project. The total score was 1830 .

Paired t-test was carried out to find out whether there was a significant difference between the group's means before and after the treatments. The paired t-test formula in SPSS 21.0 was used to analyze the pretest and posttest scores. The steps of analyzing paired t-test are follow. First is stating the hypothesis, there are:

$\mathrm{HO}$ : there is no significant difference between pretest and posttest means of the group.

H1 : there is a significant difference between pretest and posttest means of the group.

Then, stating the level of significance t 0.05 (two-tailed). Compare the value of level significance and significance value after the analysis. If significance value is equal or lower than 0.05 , the result is statistically significant.

Then H0 is rejected; meanwhile, if significance value is higher than 0.05 , the result is not statistically significant, then H0 is retained (Hatch \& Farhady, 1982:88). The result of the computation is as follows.

Table 2: Paired Samples Statistics.

\begin{tabular}{|c|c|c|c|c|c|}
\hline & & Mean & $\mathrm{N}$ & Std. Deviation & $\begin{array}{l}\text { Std. Error } \\
\text { Mean }\end{array}$ \\
\hline \multirow[t]{2}{*}{ Pair 1} & PreTest & 69.4000 & 20 & 6.12501 & 1.36959 \\
\hline & PostTest & 79.8000 & 20 & 6.28783 & 1.40600 \\
\hline
\end{tabular}

The output of group statistic shows that the mean of the pre-test was 69,40 and the mean of post-test was 79.80. The table above shows that the mean of post-test score is higher than the pre-test score. And N (number of the case) for each class was 20. Standard deviation of pre-test was 6.123 and standard deviation of post-test was 6.287. Standard error of mean of the pre-test class was 1.369 and standard error of mean of the post-test was 1.406 .

Table 3: Paired Samples Correlations.

\begin{tabular}{|ll|r|r|c|}
\hline & \multicolumn{1}{|c|}{ N } & Correlation & Sig. \\
\hline Pair 1 & PreTest \& PostTest & 20 & .576 & .008 \\
\hline
\end{tabular}


The Paired Samples Correlation table adds the information that pre-test and post-test scores are significantly positively correlated $(\mathrm{r}=0.576)$.

Table 4: Paired Samples Test.

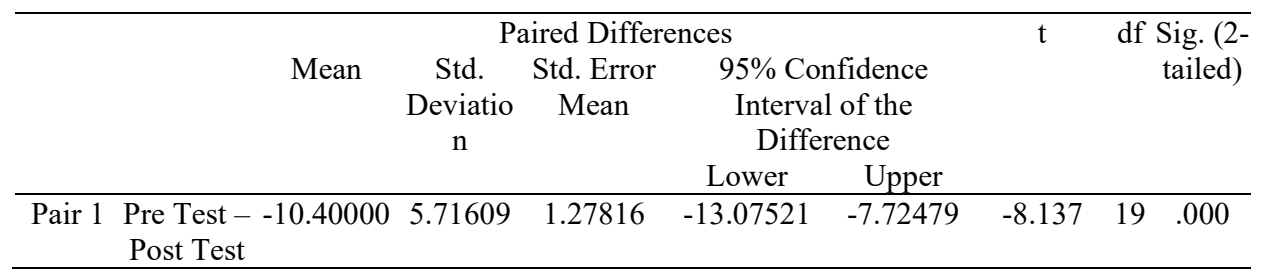

From the table above, it shows that the significance value is 0.00 , which is lower than 0.05. it means $\mathrm{H} 0$ was rejected. This computation implies that there was a significant difference between pre-test and post-test means of the class. In other words, the teaching taught PBL improved students' ability in writing business letters.

\section{Conclusions}

This research was conducted to find out whether there is a significant effect of using PBL toward writing ability or not. It is indicated from the students' writing scores and their responses after receiving the treatment of this method. Also, the students' writing skill enhanced which are get know the format of business letters, the term or common expressions which are used writing business letter, the definition, intention, purposes, and style of business letter after receiving the treatments of teaching PBL in writing business letters. It is shown from the statistical computation in which the result of the t-test calculation shows that the mean of the pre-test was 69,40 and the mean of post-test was 79.80 . The table above shows that the mean of post-test score is higher than the pre-test score. It indicates that teaching PBL gives positive effects on students' ability in writing business letter.

Moreover, the paired t-test calculation shows the result of paired sample test $(0.00<$ $0.05)$ in which there is a significant difference between pre-test and post-test scores after having treatments. In addition, the results suggest that teaching through PBL gives positive effects on students' ability in writing business letters. To follow the conclusion, the lecturers are recommended to implement this method since teaching PBL is effective to help students to write better, particularly in writing business letters.

\section{References}

[1] Barthos, Basir. 2005. Manajemen Kearsipan. Jakarta : PT Bumi Aksara.

[2] Beare,K. 2017. Vocabulary for Writing Business Letters. From : https://www.thoughtco.com/vocabulary-for-writing-business-letters-1210145

[3] Bell, S. 2010. Project-based learning for the 21st century: Skills for the future.Clearing House: A Journal of Educational Strategies, Issues and Ideas , v83 n2 p39-43

[4] Brown, H. Douglas. 2001. Teaching by Principles (An Interactive Approach to Language Pedagogy). San Francisco State University: Longman,, 2nd Ed

[5] Colley.K. 2008. Project-Based Science Instruction: A Premier. An Introduction and Learning Cycle for Implementation Project-Based Science. The Science Teacher Vol. 75. 
[6] Fried-Booth, Diana L. 2002. Project Work. Oxford : Oxford University Press.

[7] Hatch \& Farhady.1981. Research design and statistics for applied linguistics. Rowley, MA: Newburry.

[8] Hutchinson, Tom and Waters, Alan. 1987. English for Specific Purposes. Scotland : Cambridge University Press .

[9] Krauss, Jane and Boss, Suzie .2013. Thinking Through Project-Based Learning : Guiding Deeper Inquiry. Corwin Publishing a SAGE company.

[10] Mustofa. 2000. Pembinaan Kemampuan Menulis Bahasa Indonesia. Jakarta : Erlangga.

[11] Thomas, J.W. 2000. A review of research on project-based learning. Retrieved from http://www.bobpearlman.org/BestPractices/PBL_Research.pdf.

[12] Robinson, P. C. 1991. ESP today: A practitioner's guide. Englewood Cliffs, NJ: Prentice Hall.

[13] Sedarmayanti.2009. Sumber Daya Manusia dan Produktivitas Kerja. Bandung: CV. Mandar Maju.

[14] Solomon, G. 2003. Project-based learning: A primer. Tech \& Learning. Retrieved from http://pennstate.swsd.wikispaces.net/file/view/pbl-primer-www techlearning com.pdf

[15] Spratt, Mary, Pulverness, Alan, and Williams,Melanie. 2005. The TKT Course: Teaching Knowledge Test. Cambridge : Cambridge University Press.

[16] Stoller, F. 2002. Project work: A Means to Promote. Journal : Methodology in language teaching: An anthology of current practice.

[17] Suparno dan Mohammad Yunus. 2008. Keterampilan Dasar Menulis. Jakarta: Universitas Terbuka. 